Revue d'histoire du XIXe siècle

Société d'histoire de la révolution de 1848 et des

révolutions du XIXe siècle

$5 \mid 1989$

Histoires de centenaires, ou le devenir des révolutions

\title{
1870-1970, le centenaire de la République
}

Philippe Vigier

URL: http://journals.openedition.org/rh19/39

DOI: $10.4000 /$ rh19.39

ISSN: $1777-5329$

Publisher

La Société de 1848

Printed version

Date of publication: 1 June 1989

ISSN: 1265-1354

Electronic reference

Philippe Vigier, «1870-1970, le centenaire de la République », Revue d'histoire du XIXe siècle [Online]

5 | 1989, Online since 09 September 2008, connection on 21 April 2019. URL : http:// journals.openedition.org/rh19/39; DOI : 10.4000/rh19.39

This text was automatically generated on 21 April 2019

Tous droits réservés 


\title{
1870-1970, le centenaire de la République
}

\author{
Philippe Vigier
}

\section{ABSTRACTS}

No abstract available by now

Pas de résumé disponible actuellement

INDEX

Mots-clés: Commémoration, 1870 